\section{Sheltered Housing in Britain - An Approach to Managing the Housing Needs of the Elderly}

\begin{abstract}
The official statistics which are used by the British government to measure population and housing trends define the elderly population by official age of retirement. This is despite the fact that the age of retirement differs for males and females - being 65 and 60 years respectively.
\end{abstract}

Table 1: Composition of the Population in 1991 (England)(millions)

\begin{tabular}{|l|r|}
\hline Aged less than 60/65 & 39.3 \\
\hline Aged 60/65 & 5.5 \\
\hline Aged 75+ & 3.2 \\
\hline
\end{tabular}

Source: OPCS 1989 Pop Proj.

Series PP2 No16 (Quoted in Leather P. Kirk H.: Age File the Facts, Anchor Housing Trust, Oxtord, 1991)

The above table shows information which relates to England only. The elderly population of the UK is distributed across the constituent countries in a proportion which broadly follows the general population as a whole.

The number of elderly people has grown steadily throughout this century. But an even more significant trend is the increase in the number of very elderly within the post-retirement age group.
Table 3 shows the change in the make-up of the elderly population in age bands from 1901 and projected forward to 2021 .

As can be seen from the above table there has been a steady increase in the proportion of very elderly people within the older population; and in particular a significant increase in the $75+$ age group. The general population will be 'older' in future years. This is not just because people are living to a greater age. It is also a product of declining fertility rates which means that there are proportionately fewer young people in the population now than previously (and still decreasing).

Throughout the remaining years of the 1990's it is likely that older people will make up about $18 \%$ of the whole population. In the next century projections suggest that there will be a significant increase in the proportion of elderly people. Firstly, because of a continuation in the trend towards fewer births per adult female in the national population, as identified above; but also because people born in the post Second World War 'baby boom' will reach retirement age in the first decade of the new century. The numbers in
Table 2: People of pensionable age in the United Kingdom, 1991

\begin{tabular}{|l|c|c|}
\hline & Population & \% of UK Total \\
\hline \hline England & 8.796 .207 & $84 \%$ \\
\hline Wales & 570.932 & $5 \%$ \\
\hline Scotland & 908.485 & $9 \%$ \\
\hline Northern Ireland & 228.000 & $2 \%$ \\
\hline \hline UK Total & 10.504 .045 & $100 \%$ \\
\hline
\end{tabular}

Source: OPCS, 1993, Table 1
Housing Characteristic population groups Elderly people Social policy Housing policy Great Britain

The principal response by providers of public and social rented housing to the housing needs of older people has been to provide "sheltered" housing. Has this emphasis on sheltered housing been the most appropriate housing management solution to the housing problems of older people? This paper presents a brief case study illustrating two categories of sheltered housing scheme.

\section{Mary Griffiths}

Bivališča $v$ Britaniji - pristop $k$ reševanju stanovanjskih potreb starejših občanov

Stanovanja Značlne skupine prebivalstva Stari ljudje Socialna politika Stanovanjska politika Velika Britanija

Institucije, ki skrbijo za oskrbo z javnimi in socialnimi najemnimi stanovanji, so se na stanovanjske potrebe starejših obcanov odzvale z zagotavljaryem "zatočišč." Ali je povdarekna "zatočiščih" bil najbolj ustrezni pristop k reševanju stanovanjskih potreb ostarelih? Ta prispevek na kratko predstavlja dve kategoriji zatočišč za starejšse občane. 
that age group are likely to increase by $33 \%$ between 2001 and 2027 from 8.9 million to 11.7 million people.

Of greatest significance from the above scenario will be the increase in the numbers of those aged 75 years or more; this suggests that within a generation nearly a quarter of the iotal population will be in the post-retirement age bracket. But within this group an increasingly significant proportion will be aged 85 years plus, an increase of 0.2 million by the turn of the century, and a further increase of 0.25 million in the first decade of the next century. These are very significant changes in our population when considered in their own right. They become even more significant when seen alongside parallel changes in the make up of the population, and when considering the problems which increasing frailty brings to older people.

Women have a longer life expectancy than men. This means that a large proportion of the ToldU old -

Table 3: Changes in the make-up of the elderly population

\begin{tabular}{|l|c|c|c|c|c|c|c|c|}
\hline \multirow{2}{*}{ Age } & 1901 & 1951 & 1971 & 1981 & 1991 & 2001 & 2011 & 2021 \\
\cline { 2 - 9 } & $\%$ & $\%$ & $\%$ & $\%$ & $\%$ & $\%$ & $\%$ & $\%$ \\
\hline \hline $60-64$ & 37 & 30.7 & 30.3 & 25.7 & 24.2 & 23.5 & 27.5 & 25.3 \\
\hline $65-69$ & 25.9 & 26.2 & 25.7 & 24.5 & 23.2 & 21 & 21.9 & 21 \\
\hline $70-74$ & 18.6 & 20.5 & 19.1 & 21 & 19 & 18.9 & 17 & 20.4 \\
\hline $75-79$ & 10.9 & 13.3 & 12.8 & 15 & 15.5 & 16 & 13.5 & 14.6 \\
\hline $80-84$ & 5.5 & 6.4 & 7.5 & 8.5 & 10.6 & 10.9 & 10.2 & 9.5 \\
\hline $85-89$ & $2.1^{*}$ & $2.8^{*}$ & 3.4 & 3.7 & 5.3 & 6.4 & 6.4 & 5.7 \\
\hline $90+$ & 0 & 0 & 1.2 & 1.5 & 2.2 & 3.3 & 3.5 & 3.4 \\
\hline \hline Totals & 100 & -100 & 100 & 100 & 100 & 100 & 100 & 100 \\
\hline
\end{tabular}

Note: ${ }^{*}=$ includes $90+$ pop.

Source: Tinker, A. et al, 1994

Table 4: Ill Health in Old Age

\begin{tabular}{|l|c|c|c|}
\hline \multirow{2}{*}{} & \multicolumn{3}{|c|}{ AGE GROUP } \\
\cline { 2 - 4 } & $65-74$ & $75+$ & All ages \\
\hline \hline Long standing illness \% & 40 & 53 & 19 \\
\hline GP consultation in last 14 days \% & 16 & 20 & 14 \\
\hline Outpatient in last 3 months \% & 18 & 20 & 14 \\
\hline
\end{tabular}

Source: OPCS General Household Survey, 1988; quoted in: Age File the Facts (op cit). those over 75 years - will be women living alone. Already $75 \%$ of all wornen over the age of 70 years currently live alone. (Mackintosh et al.: 20).

Although the majority of elderly people retain good health well into their retirement, there are many illnesses and corresponding disabilities which are age related. In particular the 'old' old are likely to suffer increasing mobility problems, affecting how they cope with stairs, gardens or every day tasks like dressing themselves and preparing meals.

'...disability rates start to climb steadily after 50 becoming particularly steep over 70 . The most severe levels of disability remain low until about 70 and then rise quickly. From about 75 more people have some level of disability than do not. Increasing disability with age means a growing dependency on others. Nearly one half of those $85+$ are unable to walk down the road unaided and nearly a third cannot manage stairs unaided.' (An Ageing Population, Fact Sheet 2. Family Policy Studies Centre, London 1991)

The most common disabilities suffered by old people are mobility, hearing and personal care difficulties; $75 \%$ of people aged 80 or more have some form of disability. The problems of ill health also occur with more frequency after the age of 75.

There is a strong correlation between disability, ill health and low income. So the statistics quoted above have a bearing not only upon elderly people's ability to cope with their day to day personal and practical care, there is also a link with poor quality housing. Indeed single elderly ill or disabled people have the lowest income levels of all disability groups in Britain, which suggests they may have more limited choices about their accommodation in an increasingly market orientated housing economy.

Elderly people with mobility and health problems often depend he- 
avily upon the support given to them by informal carers - who are often female relatives, usually daughters. In future the supply of informal carers may well decline as the proportion of women of working age who are actually in full-time employment increases.

Interestingly the elderly population is not evenly distributed throughout the country, so the pressures upon agencies providing housing and care are also different. The highest concentrations of older people are to be found:

'...along the South Coast of England: Coastal areas of North Wales, Lancashire, Yorkshire, Lincolnshire and East Anglia; inland areas such as the Cotswolds, Mid Wales and the Welsh Borders, Yorkshire Dales and southern Lake District; and in Scotland: Dumfries, Borders, Tayside, and parts of the Western Isles and Highlands' (Mackintosh, 1990 op cit)

Some areas have actẻd as a magnet for retirement purposes, putting a strain on housing and care services. For contrasting reasons, areas which experienced expansion 40 years ago - the new towns and the post war suburbs - are also experiencing an ageing population profile - reflecting the migration pattern of young families to areas where employment prospects are better.

Data about household composition is crucial when planning new dwellings and services, and also when trying to make-best use of existing stock by minimising under-occupation of family dwellings. The majority of elderly people live in one or two person households, requiring one or two bedroomed accommodation.

As we saw above, in 1991 there were 6.3 million older households - equivalent to nearly $34 \%$ of all households. The number of lone person older households is projected to increase to 3.5 million by 2011 . Yet the largest proportion of the full range of housing stock is still family sized dwellings.
Elderly people are also disproportionately affected by housing disrepair within the housing stock; the 1986 English House Condition Survey found that older people were more likely to occupy houses which were in need of repair or lacked basic amenities. This is partly explained by the tendency of people to age with their property, but also illustrates the correlation between low income and old age - which limits the capacity of older people to carry out repairs and maintenance to their homes when increasingly needed.

The type of housing older people occupy (the tenure pattern) is changing, as a result of shifts in the general tenure pattern in the last 15 years when owner occupation has been vigorously promoted by government as the 'natural' tenure of choice.

So in future years there will be growing numbers of elderly people living in dwellings which they own - either with a mortgage or outright (mortgages having been paid up). At present most providers of social rented housing expect people who own their own houses to be able to solve their own housing problem by buying something smaller and more suitable; in practice few can gain access to the social rented sector because of these access rules. This may have to change unless private developers respond to the potential growing market for small easy to maintain housing for this group.

Table 5: Housing Tenure by age of head of household, Great Britain, 1991

\begin{tabular}{|l|c|c|c|c|c|c|c|c|}
\hline & Under 25 & $25-29$ & $30-44$ & $45-59$ & $60-64$ & $65-69$ & $70-79$ & $80+$ \\
\hline *Owned & 36 & 59 & 75 & 75 & 69 & 62 & 56 & 52 \\
\hline Rented: & 31 & 27 & 17 & 18 & 23 & 32 & 32 & 36 \\
\hline local authority & 5 & 3 & 2 & 2 & 2 & 2 & 4 & 5 \\
\hline housing association & 25 & 10 & 4 & 3 & 4 & 3 & 7 & 6 \\
\hline private ** & 3 & 2 & 2 & 2 & 2 & 0 & 0 & 0 \\
\hline other & $100 \%$ & $100 \%$ & $100 \%$ & $100 \%$ & $100 \%$ & $100 \%$ & $100 \%$ & $100 \%$ \\
\hline total &
\end{tabular}

* includes outright ownership and ownership with a mortgage

includes furnished and unfurnished lettings

Source: adapted from OPCS, 1993, Table 3.32b. 


\section{Sheltered Housing}

The principle response by providers of public and social rented housing to the housing needs of older people has been to provide TshelteredU housing. There are now more than 460,000 sheltered housing units in England, 300,000 of which are owned by local authorities. The rate of provision has declined considerably in the 1990's and the reduction in new-build has only partially been filled by housing associations and the private sector. The number of completions by sector are shown in the following figure:

In Scotland; too, there was a big increase in the construction of sheltered housing in the 1980's. The size of the stock of sheltered housing increased from 8,487 units in 1980, to 31,632 in 1991. (Scottish Office Social Work Services Group, 1993). This rate of production is impressive. Tinker (et al) point out that ... 'in the ten years to 1989, England's total housing stock rose by $10 \%$, but the number of sheltered units by $69 \%$.'

Has this emphasis on sheltered housing been the most appropriate housing management solution to the housing problems of older people? There has been little research carried out as to why sheltered housing was the preferred option for local authorities in this period - but

Table 6: Completions of new specialised dwellings for elderly people: by sector.

\begin{tabular}{|l|c|c|c|c|}
\hline \multirow{2}{*}{} & \multicolumn{5}{|c|}{ Number of dwellings } \\
\cline { 2 - 5 } & 1981 & 1986 & 1991 & 1992 \\
\hline \hline *Sheltered housing & 130 & 850 & 1,501 & 1,266 \\
\hline Private enterprise & 1,929 & 1,916 & 1,243 & 1,535 \\
\hline Housing Association & 5,558 & 3,722 & 1,569 & 677 \\
\hline Local authorities/new towns & 62 & 193 & 279 & 409 \\
\hline \hline Other housing & 261 & 597 & 598 & 535 \\
\hline Private enterprise & 4,636 & 1,778 & 289 & 92 \\
\hline Housing Association & 12,576 & 9,056 & 5,479 & 4,514 \\
\hline Local authorities/new towns & & & & \\
\hline $\begin{array}{l}\text { All new specialised dwellingsfor } \\
\text { elderly people }\end{array}$
\end{tabular}

Note: "figures for 4 th quarter not complete

Source: Tinker, A. et al., 1994:21. in the 1970's it was a solution which was promoted by official government policy.

\section{What is Sheltered Housing?}

Government encouragement of specialist housing provision for elderly people really began shortly after the Second World War, with the introduction of the Welfare State. The 1948 National Assistance Act gave local authorities a statutory duty to provide care for the elderly. A grant was made available, through the local authorities, to develop or convert accommodation specifically for elderly people.

Indeed it is through this legislation that local authority residential care homes in particular, were provided by social services departments within the upper tier of the two-tier local authority system in Britain. These came to be known colloquially as 'Part III accommodation'. This type of accommodation was generally provided and managed by Social Services Departments because of the high level of care provided to residents. People accommodated were assessed as being unable to live independently in their own homes, as they needed personal care and support. The residential care homes provided all meals and had staff available for 24 hours a day. However, the regimes within these schemes were often dictated more by the management needs to organise staff teams to provide roundthe-clock care within shift systems, as they were to meet the actual support needs of the residents.

By the 1960's there was a shift of opinion against residential and institutional care in all settings because problems of resident institutionalisation were emerging, and at the same time it was recognised that people in such schemes were vulnerable to exploitation and even abuse by staff. For example Peter Townsend in 'The Last Refuge' (1962) argued that:

- residents of Part III accommodation had a low quality of life,

- routines of care were designed to suit staff rather than residents,

- life was too heavily regimented, 
- there was a lack of stimulating activity for residents

- many residents had both the physical and mental ability to care for themselves.

Elderly people themselves often feared being accommodated in residential 'Part III' accommodation because of the loss of dignity and independence which it involved. It was the norm for bedrooms to be shared by residents who were not previously known to each other and of course there was little room for people to bring with them their own furniture and possessions, still less to continue with their own life style. Residential care had imposed communal life on people who would not normally have chosen this life style, but who, because of their inadequate housing or inability to cope with some every day tasks unaided, could no longer cope in their own home.

This exposure of the problems of institutional care brought about a shift in emphasis in social policy away from such facilities towards systems designed to enable the elderly to remain in the community wherever possible. This led to innovations in housing with the aim of safeguarding peopleUs independence for as long as possible. The emerging design ideas which were shaping specialist housing for the elderly were given greater clarity as the result of new government guidance in the late 1960's.

The concept of Sheltered Housing was defined and developed by guidance produced by the then Ministry of Housing and Local Government (later to become the Department of the Environment). Their advice was disseminated to local authorities in England and Wales through publications known as 'circulars'. At that time local authorities provided much of the funding to housing associations for new developments, and so the design ideas for sheltered housing were also transmitted to these housing providers too.

There are two types of sheltered housing designed specifically for elderly people described by the first Circular (No. 82/69) on the subject, entitled 'Housing Standards and Costs: accommodation specially designed for old people' 1969. It is the 'Categories' of scheme types described in this official guidance which soon entered the language and are still embedded in housing parlance. They have become shorthand names to describe sheltered housing. They are as follows:

\section{Category 1:}

Mandatory Standards:

1. hand rails

2. special locks

3. fridge or vented food storage

4. high standards of heating

Other optional features which did not attract subsidy

\section{Category 2:}

1. mandatory floor areas which are less than in Cat.1. offset by the inclusion of communal areas within schemes

2. communal provision

3 . individual cookers

4. emergency alarm system

5. self-contained wardens accommodation

Schemes had to comply with these mandatory standards in order to qualify for the enhanced housing subsidy which sheltered housing attracted from 1969 onwards. However the Local Government Planning and Land Act, 1980, abolished these standards and led to Circular $82 / 69$ being withdrawn. Local authorities subsequently set their own standards whilst houising associations followed the design and contract criteria published by the Housing Corporation - the funding agency to which housing associations apply for financial support for new development. But the advice contained in the circular had become deeply ingrained, and still has a strong influence upon the design of sheltered housing. In addition to these design features sheltered housing usually also includes some or all of the following : a resident warden or a responsible person who acts as a 'good neighbour'; an alarm system to each dwelling which when activated alerts the warden/good neighbour that a resident needs 
help. Usually schemes are purpose built though some schemes have been provided through conversion of existing buildings. In addition, most schemes have dwellings which are usually grouped together on one site - sometimes as a mixture of Category 1 and Category 2 accommodation units. All have an occupancy which is confined exclusively to elderly people. Occasionally younger people who have a need for a comparable level of support, because they are physically disabled for example, may be housed within a sheltered housing scheme. The day to day costs of running schemes in the local authority sector, including the Wardens costs, are usually borne by the Housing Revenue Account which is the financial account into which all income from renting out L.A. property is paid. Occasionally the non-housing costs (that is anything which would more accurately be defined as TcareU) are met by the Social Services Departments, from their own revenue budget; usually only where a scheme has been jointly planned by both housing and social services departments.

Some housing associations have specialised exclusively in providing sheltered housing for the elderly e.g. Hanover Housing Association and Anchor Housing Association. Even housing associations with a more mixed stock profile have significant levels of sheltered housing.

The following brief case study provides an illustration of the two categories of sheltered housing scheme. Both have been developed by a national housing association; about $25 \%$ of their stock is specialist housing for the elderly, the rest being largely mainstream family housing.

\section{Case Study Examples}

A. Typical Category One Scheme:

- Scheme was built in 1979.

- Consists of 28 units.

- Good NeighbourU helper.

- Alarms: Pull cords are situated in flats and connected through to Good Neighbour. There is no speech facility.
- The rents levied range from $£ 36.00$ for a secure tenancy to £ 47.00 per week for an assured tenancy.

- Other services include caretaker, grounds maintenance, communal lighting and cleaning and external window cleaning, see attached schedule.

- The Good Neighbour works Monday - Friday, 9.00am-11.00am and priority is given to checking on all residents to ensure they are in good health. Should they be found to be in need of medical assistance this is done immediately.

- Once all residents are visited other duties can be attended to eg reporting repairs.

- The Cat I properties are on the ground and first floor with general purpose properties on the second floor. There are no lifts on site.

- There are no communal facilities on site.

\section{B. Typical Category Two Scheme:}

- Scheme was built in 1986.

- Consists of 46 units.

- Resident Warden.

- Alarms: The system is connected through to a Central Control based in an adjacent town, who cover whilst the Warden is off duty. The Tunstall Telecom Piper Group system benefits from a two-way speech facility which enables the Warden to speak to the tenant.

- The rent levied range from \#45 for secure and $£ 67$ for assured per week depending on the type of tenancy. Along with the residential warden, there are other services which are listed on the attached schedule.

- The Warden works Monday-Friday, $9.00 \mathrm{am}$ to $5.00 \mathrm{pm}$ and priority is given to checking on all residents to ensure they are in good health.

- Once all residents are visited other duties can be attended to eg. reporting repairs, laundry tokens, coffee mornings. Communal facilities include common room, laundry and guest room.

- The scheme is built on 3 floors with a lift. 
Despite the withdrawal of Circular $82 / 69$ in 1980 , the standards within sheltered housing continued to evolve so that sheltered schemes developed in the 1980's and to date include guest rooms in which friends and relatives can stay for a small charge - the idea is to facilitate continuing contact and support from relatives who may live some way away from the scheme. Residents usually have use of a laundry room containing washing machines and tumble dryers, irons and ironing boards; and activities or hobbies room(s) where all manner of activities can be continued - such as carpentry, arts and crafts, gardening etc.

In addition to self contained accommodation the warden in charge of a scheme will usually also have an office where the residents personal records will be stored, where private interviews can be held and where the hub of the alarm system will be housed.

In the 1980's the Chartered Institute of Housing and the Royal Institute of British Architects produced a 'Housing Design Brief: Housing for Elderly People', that aimed to ensure that the following features were designed into schemes in order to:

- Facilitate independence - e.g. locate power points at waist height; ensure that windows can be easily opened;

- Maximise personal space and privacy - this therefore precludes shared facilities;

- Provide safety aids e.g. hand rails, but ensure that they do not become overly obtrusive;

- Ensure that taps etc. can be easily manipulated allowing for reduced grip;

- Provide a stimulating environment within the dwelling in order to offset as far as possible the reduced contact with the outside world which frailty brings e.g. an interesting aspect and windows which provide a view when seated;

- Avoid potential disorientation of tenants by avoiding overly complex layouts - with long corridors which may quickly become rabbit warrens;
- Maximise the possibility of contact between tenants whilst preserving private space e.g. by grouping flats or bungalows into small groups of four;

- Provide small or easily managed dwellings;

- Efficient and cheap heating;

- Locate near to amenities and community services;

- Locate on a site with good access to public transport;

- Provide level access to the site with no steep gradients;

- Privacy;

- Provide manageable garden - or no garden;

- Provide pleasant environment;

- Physical security;

- Minimal concentration of specialist dwellings.

There is now greater effort to minimise the institutional feel of sheltered housing with a view to maximising independence and privacy of tenants and normalising - theirU housing - that is making it as near to TordinaryU housing as possible.

It should be borne in mind that the figures are likely to be under rather than overstated as not all local authorities will have precise data for schemes in their area. The uneven distribution of schemes reflects the ad-hoc nature of planning at the local level and the total lack of strategic regional and national planning for specialist housing for this group.

Table 7: Regional Distribution of Sheltered Housing

\begin{tabular}{|l|r|r|r|r|r|}
\hline \multicolumn{1}{|c|}{ REGION } & $\begin{array}{r}\text { local } \\
\text { authority }\end{array}$ & $\begin{array}{r}\text { housing } \\
\text { assoc'n }\end{array}$ & private & total & $\begin{array}{r}\text { units per } \\
\text { 1,000 pop'n }\end{array}$ \\
\hline north & 23,631 & 8,040 & 397 & 31,798 & 12.3 \\
\hline yorks and humberside & 39,776 & 10,598 & 1,093 & 51,467 & 10.4 \\
\hline east midlands & 35,110 & 7,364 & 1,098 & 43,572 & 10.9 \\
\hline eastern & 37,944 & 13,387 & 5,078 & 56,509 & 9.9 \\
\hline greater london & 26,068 & 16,114 & 4,248 & 46,430 & 6.9 \\
\hline south east & 34,955 & 19,475 & 15,154 & 69,584 & 10.0 \\
\hline south west & 33,639 & 12,192 & 6,255 & 52,086 & 11.2 \\
\hline west midlands & 29,713 & 10,649 & 2,194 & 42,556 & 8.6 \\
\hline north west & 42,495 & 22,981 & 3,281 & 68,757 & 10.0 \\
\hline \hline total & 303,061 & 120,800 & 38,798 & 462,659 & 9.7 \\
\hline
\end{tabular}

(Scotland 31,632 4)

Source: Age File the Facts, 1994:21 (Information for Scotland, Tinker, 1994, op cit). 
Peter Townsend in 'The Last Refuge' in the 1960's recommended that 50 sheltered dwellings should be provided for every 1,000 elderly people in the population. This benchmark has not been adopted as the above illustrates.

Anthea Tinker (et al) points out that:

There is very little national guidance in England and Wales on how much housing is needed by elderly people. and what form it should take. However, the Department of the Environment started research on housing needs and provision ... and hopes to issue guidance after the completion of the study ...

The Scottish Office issued national guidance for Scotland in 1991 suggesting 20 units of very sheltered housing, 46 units of sheltered housing and 80 units of medium dependency housing per 1,000 people aged 65 and over (Tinker, 1994:22).

In 'Sheltered Housing for the Elderly', by A Butler, C Oldman and J Greve, published in 1983, the authors criticised the over- emphasis placed upon sheltered housing as a cure-all for the housing problems experienced by older people. They acknowledged that sheltered housing represented a substantial improvement in accommodation standards for those who were re-housed from unfit, un-modernised or unsuitable housing. But they did not find, in their national study of provision, that all or most tenants either needed or wanted the wardenUs services or even the alarm scheme.

'What is not altogether clear is why somebody living in poor housing conditions should be seen as a candidate for a form of specialised housing, when apparently their requirements could have been met in other ways - either by home improvements or a move to better quality housing.'

Indeed some very real problems with sheltered housing were identified by this study in the 1980's:

- sheltered housing had been provided to the virtual exclusion of other alternatives;
- a fudging of objectives - especially as between the 'housing' as opposed to the Tcare' elements;

- they created age-based ghettos and as a result tenants became separated from the wider community;

- they tend to increase dependency - not all tenants need supervision or care;

- not all tenants had actively chosen the sheltered option. They had become sheltered tenants because of a) the lack of other housing options, or b) because their local authority was seeking to reduce under-occupation of L.A. family sized housing;

- many tenants would have preferred to have remained in their former home.

Even where tenants had been appropriately re-housed they sometimes became too frail to cope on their own, but had difficulty securing the additional care they needed.

On the other hand this kind of 'housing with care' is cheaper than other forms of Tcare and support' provided in other settings. This was shown by figures produced in the 1980's:

Table 8: The cost per person (in £'s) per annum inclusive of all supportive services (figures 1981-2):

\begin{tabular}{|c|c|}
\hline & $1981-2$ \\
\hline \multicolumn{2}{|l|}{ 1. Hospital: } \\
\hline acute & 20,319 \\
\hline long stay & 15,347 \\
\hline geriatric & 14,8142 \\
\hline 2. Part III & 5,9533 \\
\hline \multicolumn{2}{|c|}{ 3. Sheltered Housing } \\
\hline local authority & 4,940 \\
\hline housing assoc'n & 4,971 \\
\hline
\end{tabular}

The group included in these costings were people of high dependency who were in receipt of state benefits.

More recent figures published by the DoE compare sheltered housing costs with those of support services provided to people in their own 
homes. This comparison was rather less favourable to sheltered housing - but institutional/residential care is not included in this comparison (Table 9).

Irrespective of all the arguments about costs, and the relative merits of people moving as opposed to staying in their own homes - all the research into tenants attitudes have uncovered very high levels of satisfaction with this form of housing. The aspects of schemes which are most highly valued by tenants are the warden's service, the physical security provided by schemes and the social contact which is made possible. Recent surveys of sheltered housing tenants are also finding that new residents are older and more frail than existing tenants, and are certainly more frail than were new tenants 10 years ago. This is not only because of demographic trends, it also marks a change in the management of schemes. The concept of sheltered housing with a warden originally included the idea of housing people with a range of different abilities so as not to overburden the warden with an over dependent population within any one scheme, and also so that the more able tenants could help the more frail.

A further development of the concept has also taken place in response to an increasing need for provision to meet the needs of the frail elderly. This is known as Very Sheltered Housing or Extra Care schemes.

\section{'Very Sheltered Housing' or 'Extra Care Schemes'}

In response to the increasing care needs of sheltered housing tenants, many local authorities and housing associations developed schemes which were designed to provide a higher level of care and support. These were known as 'Very Sheltered Housing' or 'Extra care Schemes', or even - because of their interim status between sheltered housing and Part III accommodation-Part $21 / 2$ schemes (Table 10).
The main reasons for providing this type of housing were that:

- tenants were becoming more frail in sheltered housing,

- Part III accommodation was increasingly seen as inappropriate,

- to provide care yet independence,

- the wish to widen choices available to older people,

- an attempt to prevent hospitalisation.

The additional features provided within extra care housing are usually: some meals; 24 hour cover by a warden or other help; and enhanced communal facilities such as a dining room. The Very Sheltered Housing Schemes built had often resulted from close inter-agency cooperation especially between housing and social services departments - this was usually co-ordinated by the housing department.

'There was evidence that some authorities were coming towards an inter-agency approach. which included the voluntary sector, to solve all the needs of elderly people. One District Health Authority said we are getting acceptance that we are jointly (DHS, LA and voluntary sector) caring for the elderly'. A housing department agreed because without such co-operation 'District Councils are probably not keen to take the

Table 9: Comparative Costs of provision of care and support

\begin{tabular}{|l|c|c|c|}
\hline & $\begin{array}{c}\text { low } \\
\text { dependency }\end{array}$ & $\begin{array}{c}\text { medium } \\
\text { dependency }\end{array}$ & $\begin{array}{c}\text { high } \\
\text { dependency }\end{array}$ \\
\hline \hline stay at home & 4565 & 4409 & 4429 \\
\hline specially designed housing & 5699 & 5830 & 5840 \\
\hline sheltered with warden & 6519 & 7053 & 7377 \\
\hline very sheltered & 11,299 & 11,902 & 12,564 \\
\hline
\end{tabular}

Table 10:

\begin{tabular}{|l|l|}
\hline \multicolumn{1}{|c|}{ ADVANTAGES } & \multicolumn{1}{|c|}{ PROBLEMS } \\
\hline $\begin{array}{l}\text { Cheaper than Part III residential care } \\
\text { High degree of tenant satisfaction }\end{array}$ & $\begin{array}{l}\text { More expensive than care in the home } \\
25 \% \text { residents said they would have } \\
\text { preferred not to move }\end{array}$ \\
\hline $\begin{array}{l}\text { Provide frail elderly with greater } \\
\text { independence than Part liI }\end{array}$ & $\begin{array}{l}\text { Schemes varied in the frailty of their } \\
\text { residents.ie. selection methods were ill } \\
\text { defined }\end{array}$ \\
\hline $\begin{array}{l}\text { More likely to have self contained } \\
\text { accommodation than in Part III }\end{array}$ & $\begin{array}{l}\text { Self contained accommodation was not } \\
\text { universally provided }\end{array}$ \\
\hline $\begin{array}{l}\text { A higher level of care than in more } \\
\text { independent accommodation }\end{array}$ & $\begin{array}{l}\text { Too much care provided 'in-house' rather } \\
\text { than involving Health and Social Services } \\
\text { Departments }\end{array}$ \\
\hline
\end{tabular}


initiative on Very Sheltered Housing, as they might be landed with people who need permanent care'. A social services department reported 'moving towards a joint strategy for the elderly with health and housing departments in the county'. Joint strategies were being developed in some areas. In East Suffolk for example the joint care planning team of health, housing and social services produced a joint strategy in 1985 including pilot schemes which were to be evaluated' (Tinker, 1984:59).

On the other hand:

'where there was not a generally agreed strategy about for whom very sheltered housing was suitable, this could lead to conflict. For example, if patients were discharged early (from hospital) with little forewarning. on the assumption that an intensive level of care would be provided' (ibid).

The availability of pump priming finance through the system mentioned above - Joint Funding - provided encouragement to the development of very sheltered housing. This finance was available to schemes which could be shown to help avoid or delay elderly people having to enter more expensive hospital or residential care. Also, such schemes. often attracted revenue funding for support posts within the scheme, in addition to resident wardens. Very Sheltered housing can provide flexible care according to need, perhaps for short periods to individual tenants; there may also be economies of scale by providing support services within this environment. This makes them the potential focus of wider community care and support services, which in turn would establish pivotal resources in the context of Community Care.

Before moving on to discuss the impact of Community Care legislation and the role of the warden, it is worth pointing out that some local authorities have been able to enhance their provision of sheltered housing by utilising existing dwelling stock. This has been a particularly attractive option open to local authorities who have housing estates which contain large numbers of high rise tower blocks; these have become unpopular with families and consequentially hard to let. Whole tower blocks can be converted to specialist sheltered housing relatively cheaply by the creation of communal facilities, attractive common areas, efficient lift systems, and with the installation of secured entry systems, even TconciergeU services. The addition of two-way speech alarm systems linked to a staff team of wardens completes the conversion. The tenants are then charged a service charge in addition to their weekly rent to cover the enhanced services, just as in ordinary low rise sheltered housing.

A further development of warden support services has been made possible through the new technology now available for alarm systems. These are now so sophisticated that some housing authorities no longer employ resident wardens; instead the alarm system when activated in the tenants flat is channelled through to a central control office where all participating tenants have their records kept on computer. The central control officer can call up the details of the caller to check for any known medical conditions and depending on the resulting two way conversation with the caller can either call out a nonresident warden, a relative or other support services including emergency medical aid. These systems have the potential to give a similar level of support to elderly people who are still living in their own homes. In short, the central control plus non resident warden support can be provided across all tenures and house types; and as such can contribute towards keeping people in their own homes despite increasing frailty. Local authorities now run their own schemes or they can purchase into schemes run on a regional basis by private companies.

It is a natural progression that, with the support and consent of existing tenants, the communal aspects of ordinary sheltered housing could be opened up to elderly dependent people living in their own homes within the locality - perhaps to provide day care services or meals, or just for social gatherings. 


\section{The Role of the Warden}

Recent research carried out by Sanctuary Housing Association illustrates the lack of clarity in this area. It was found that warden job descriptions varied widely throughout their organisation even where schemes were similar in size and design. This is mainly due to schemes being planned and built at different times. Nonetheless the result was that the expectations by tenants and relatives of the role of the warden, could be very different:

Service levels are not related to tenants' actual support needs but usually represent how the scheme services were set up at the time the scheme came into operation. Local management initiatives in some areas are attempting to introduce a more rational, planned service, but this is not uniform, more a matter of what priority it has been given by the local management team.

Sanctuary Housing Association have defined the role of the warden as covering three main areas of work as follows:

- Scheme Manager

- Service co-ordinator and facilitator

- Tenant Advocate

The following is a fairly typical job description provided to wardens of sheltered housing:

\section{Sanctuary Housing Association}

\section{Job Description}

Job Title: Warden at 46 Unit Category I and II Scheme for the Elderly

Responsible To: Housing Officer Responsible For: Cleaner

Hours of Duty:

$9.00 \mathrm{am}-1.00 \mathrm{pm} \& 2.00 \mathrm{pm}-$ $5.00 \mathrm{pm}$

5 days per week -35 hours per week

To Be Responsible For:

Managing the scheme on a day to day basis, to act as a good neighbour to residents and to be the Association's representative at the scheme.
Specific Duties:

\section{Welfare of Residents}

1. To be alert to the state of health and dependence of each resident and to take appropriate action by contacting relatives friends or relevant services as required.

2. To establish the well being of each resident before 10.00 am with follow up visits/ calls as required.

3. To respond immediately to emergency calls made by residents and summon whatever medical or other assistance may be required.

4. To liaise with local agencies and services to ensure that any assistance available to meet the specific needs of residents is utilised, eg. Social Services, nursing, medical, home help, meals on wheels, social activities.

5. To offer assistance of a neighbourly nature to tenants who may be ill for short periods, eg. collecting prescriptions.

6. To maintain a record of the doctors and nearest relatives of each resiclent and any emergency telephone numbers.

7. Where the emergency alarm is linked to an off site agency/ authority, to ensure that such details supplied to that agency, authority are kept up to date.

8. To keep the Housing Officer infomed of any cause for concern with regard to the welfare of any resident, in particularly if any resident appears to be refusing help or is becoming incapable of managing their own affairs.

Building, Equipment and Communal Areas

9. To be responsible for the security of the building.

10. To notify the office of any repairs or defects in the building which require attention.

11. To oversee the general condition of communal areas relating to the properties and report to the Housing Officer on the standard of any gardening, cleaning or general work undertaken by contractors or other employees. 
12. To instruct residents on the proper use of heating systems and alarm equipment.

13. To liaise with the local Fire Prevention Officer and ensure that fire drills, regular checks on the fire alarm system and maintenance of a Fire Book are carried out in accordance with regulations and recommendations.

14. To be genreally responsible for the Guest Room, its cleanliness, booking, etc.

15. To collect, record and pass monies to the Housing Officer for the Guest Room use and communal telephone.16. To keep an inventory of all furniture and equipment provided within the scheme which is in the ownership of the Association.

\section{General}

17. To promote the use of the communal facilities and to help organise communal activities.

18. To keep a daily log.

Any other duties consistent with the post as directed by the Housing Manager.

Some housing organisations have produced detailed Wardens Manuals which define the detailed day to day roles and responsibilities for their employees, and also provide information about the departments and agencies to which wardens may need to refer problems, as well as detailing in-house management practices and procedures.

The Centre for Sheltered Housing Studies has also proposed a Code of Practice for wardens which is supported by the professional bodies and is being adopted by an increasing number of housing agencies.

\section{Code of Practice}

1. To offer equal opportunity and fair treatment to all residents without discrimination on account of race, gender, disability, religion, age, or sexual orientation

2. To recognise, respect and safeguard the individuality and per- sonal rights of each resident whilst acknowledging the responsibilities to others

3. To understand and respect the confidentiality of knowledge and information relating to individual residents an the employer

4. To facilitate independence and the well being of residents both as individuals and within the group as a whole

5. To be sensitive and impartial in the delivery of services

6. To act always with honesty and integrity

7. To ensure that professional responsibility is never sacrificed for personal interest

8. To establish and maintain high standards of personal conduct and professional relationships

9. To acknowledge the need for continuing professional training and self-development

10. To ensure that internal procedures relating to statutory obligations of the employer are understood and implemented

11. To understand the roles of other service providers and significant people in the lives of residents and be committed to working effectively with them

12. To be aware of and to accept a responsibility to contribute to the setting of objectives, policies and procedures of the employer.

The Community Care legislation which came into force in 1993 has changed the responsibilities given to statutory agencies for the care and support of elderly people, and other need groups. The principal aim is to retain people in their own homes, living as independently as possible for as long as possible. Social Services departments have been given the responsibility for drawing up community care plans for their areas, consulting as widely as possible with other providers of services, and with users and potential users. Their role as providers of services is to greatly diminish and the residential care homes they still have in management are being transferred to outside agencies wherever possible. Rather than acting as direct providers, social services are to play the strategic role for planning these services, assessing individual 
clients needs for care and support, and purchasing 'packages' of care and support from independent suppliers of services, to meet these needs. People living in residential care homes will only receive financial support from the State for their accommodation, if the Social Services department agrees that they are in genuine need of the level of care being provided there. The Social Services departments are therefore the 'enablers' of Community Care but are not the main providers. The advantages and potential pitfalls in this re-arrangement will be explored in the annex to this paper.

Thus the way has been opened up for housing associations, in particular, to become major providers of accommodation where medium to high levels of care and support are required. Some housing associations already have experience of providing these types of scheme and have already received funding to develop innovative projects including residential care homes for elderly people who have severe mental impairment due to Alzheimers and other age related diseases.

It is likely that this trend will increase in the future; but that this will happen alongside the extension of services such as domiciliary care to people remaining in their own homes, where this is more appropriate.

Dr. Mary Griffiths, Senior Lecturer, Course Director, Post-Graduate Diploma in Housing

\section{Bibliography and Sources}

Tinker, A.: Staying at Home: Helping Elderly People, HMSO, London 1984.

Tinker, A.; McCreadie, C.; Wright, F.; Salvage, A.: The Care of Frail Elderly People in the United Kingdom. HMSO, London 1994.

An Ageing Population, Fact Sheet 2, Family Policy Studies Centre, London 1991. Age File the Facts, Anchor Housing Trust, 1994 